\title{
Introduction
}

Kyle M. L. Jones

\section{Fearless Sifting and Winnowing}

For the past three years, a black-and-white copy of a text with a fading highlighted section has been unceremoniously taped to my office wall in Indianapolis. The copy is page 184 of Amy Gutmann's (1999) book Democratic Education, wherein the section reads:

Universities serve democracies best when they try to establish an environment conducive to creating knowledge that is not immediately useful, appreciating ideas that are not presently popular, and rewarding people who are - and are likely to continue to be-intellectually but not necessarily economically productive.

For me, it has been a reminder that the value of my scholarly efforts — and that of my colleagues — should not be determined solely by their ability (or lack thereof) to generate grant funding. Try as I might to will this belief into being, it is a difficult struggle when one is enmeshed in the neoliberal academic complex. As I reflect on the articles included in this issue of Library Trends, I see Gutmann's words in a different light.

In arguing that democracies need all sorts of knowledge, even that which has no clear utility or market value, Gutmann is indirectly proffering that old adage of my alma mater, the University of Wisconsin-Madison, about "continual and fearless sifting and winnowing." What we teach, what students learn, and the ends to which both of these things are directed should not be constrained by the politics of the day and the dominant social milieu. That which is valuable is that which leads to truth, and by extension the health of a democracy.

This is the author's version of the work published as:

Jones, K. M. L. (2019). Introduction. Library Trends, 68(1), 1-4. https://doi.org/10.1353/lib.2019.0027 
In order to accomplish these lofty goals, higher education institutions must develop infrastructures and support the conditions necessary to pursue thought unencumbered by undue influence. Such things are inherently messy and always evolving, but the aims they support are worthwhile. So, when new sociotechnical systems emerge that seem at first blush to be in stark contrast to intellectual freedom or contravene students' educational interests, the moment signals a time for reflection and sharp, critical analysis. With learning analytics, that moment has come.

\section{The Library Learning Analytics Movement}

Learning analytics is the "measurement, collection, analysis and reporting of data about learners and their contexts, for purposes of understanding and optimizing learning and the environments in which it occurs" (Siemens 2012, 4). If the academic library is the "most important observation post" (Duderstadt 2009, 220) for understanding how students learn, then it follows that libraries in colleges and universities should be a primary focus of data mining and analysis initiatives in higher education. Significant efforts are underway to enable libraries to make visible their user data; data that was at one time purposefully destroyed is now full of analytic possibilities (see Oakleaf 2018).

The efficacy of learning analytics is premised on an institution's ability to identify, aggregate, and manage a wide variety and increasingly large volume of data about students, much of which needs to be identifiable in order to develop personalized, just-in-time learning interventions. So, in the fashion of other big data initiatives, institutions are beginning to dredge their information systems for student behaviors, personal information, and communications, all of which hold potential to reveal how students learn and uncover structural impediments to learning. Integration of library data in learning analytics is fledgling at best, but there are growing calls for such activity to increase, especially to enhance a library's ability to prove their resource expenditures and demonstrate alignment with wider institutional goals (e.g., improve learning outcomes, decrease costs, etc.) (see Connaway et al. 2017).

\section{Addressing the Emerging Harms}


It is enticing to assume good things about library participation in learning analytics. The profession wants to provide just the right information at just the right time, and professional librarians want that information to aid students as they develop personally, academically, and professionally. Moreover, the profession seeks to further cement its position as a key player in the educational experience, and learning analytics may enable librarians to make stronger claims about their pivotal role once they gain access to new sources of data and the metrics that come from data analysis.

But, like all technologies, learning analytics are not neutral; they are embedded with and driven by political agendas, which may not be congruent with—or necessarily aware of — extant values and ethical positions, such as those espoused by academic librarians and users of their libraries (Jones and Salo 2018). They are built upon systems of surveillance and raise serious intellectual freedom issues (Jones and LeClere 2018). With learning analytics, students are made into and considered as data objects, which effectively treats them as analytical subjects and less as humans with identities and interests (Jones and McCoy 2018). Not far from all these issues is the reality that learning analytics call into question serious issues around student privacy not encountered since the early 1970s when the Family Educational Rights and Privacy Act (FERPA) came to be (Rubel and Jones 2016). Scholars and practitioners need to take a critical approach to the growing role of learning analytics in academic libraries and the wider higher education context in order to better inform conversations concerning these and other negative outcomes learning analytics can bring about. Articles included in this issue have taken up that call, and in so doing have brought to the fore significant social, political, methodological, and ethical issues that at times are neither easy to resolve nor in alignment with those in powerful political positions within the profession — but they are needed.

\section{A Summary of the Issue's Articles}

The issue begins with Tami Oliphant and Michael R. Brundin's review of the learning analytics literature and role of big data in higher education, including a detailed review of how libraries are pursuing learning analytics. They home in on the stated values and ethical principles to which librarians 
hold strong, arguing that such things are seemingly incompatible with the aims learning analytics seek to achieve.

Respectively, the work by Sarah Hartman-Caverly and Karen P. Nicholson, Nicole Pagowsky, and Maura Seale address how temporality, manipulation, and power issues intertwined with learning analytics all act upon students and librarians in ways that diminish their autonomy and exert influence. For Hartman-Caverly, learning analytics are used to engineer student attention in ways that serve the capitalistic interests of higher education institutions. For Nicholson and her colleagues, learning analytics are a form of temporal governmentality. They argue that administrators and the politically powerful can use data analytics to scrutinize real-time performance of students and librarians, predict future outcomes (even when such outcomes are not guaranteed), and advocate for data-based interventions to resolve undesirable predicted outcomes.

M. Brooke Robertshaw and Andrew Asher's article employs a statistically driven meta-analysis strategy of library learning analytics research. The analyzed corpus included common "library value" research that suggests a positive correlation between grade-point average and library usage or library instruction. Robertshaw and Asher found, however, that the effect of such findings is statistically weak, and they argue that the potential privacy harms are not justified by the analytic practices. 


\section{Author Note}

Kyle M. L. Jones

Dr. Kyle M. L. Jones is an assistant professor within the Department of Library and Information Science within the School of Informatics and Computing at Indiana University-Indianapolis (IUPUI). His research concerns information ethics and policy issues associated with educational data-mining practices and technologies in the context of American higher education. Solo and with respected colleagues, Jones has published articles in College \& Research Libraries; The Information Society; portal: Libraries and the Academy; Learning, Media and Technology; and other journals and conference proceedings.

\section{Acknowledgements}

I am thankful for Lisa Janicke Hinchliffe's guidance; her editorial insights and careful handling of the process helped me to develop what I believe is a much-needed issue on learning analytics. A cadre of talented, professional peer reviewers provided their time and insights to help the authors of this issue make their works stronger. Their names will go unwritten, but their efforts live through the words in the included articles. Ultimately, I give thanks to the authors who responded with passion to the call for papers. Their writings, though at times sharp and uncomfortable for some, will undoubtedly help readers - and the profession — reflect on the growing momentum of learning analytics in academic libraries, and in so doing provide the intellectual tools necessary to question whether that momentum needs more friction. 


\section{References}

Connaway, Lynn Silipigni, William Harvey, Vanessa Kitzie, and Stephanie Mikitish. 2017. Academic Library Impact: Improving Practice and Essential Areas to Research. Chicago: Association of College and Research Libraries. http://www.ala.org/acrl/sites/ala.org.acrl/files/content/publications/whitepapers/academiclib.pdf.

Duderstadt, James J. 2009. "Possible Futures for the Research Library in the 21st Century." Journal of Library Administration 49 (3): 217-25. https://doi.org/0.1080/01930820902784770.

Gutmann, Amy. 1999. Democratic Education. Princeton, NJ: Princeton University Press.

Jones, Kyle M. L., and Ellen LeClere. 2018. "Contextual Expectations and Emerging Informational Harms: A Primer on Academic Library Participation in Learning Analytics Initiatives." In Applying Library Values to Emerging Technology: Decision-Making in the Age of Open Access, Maker Spaces, and the Ever-Changing Library, edited by Peter D. Fernandez and Kelly Tilton, 357-72. Chicago: Association of College and Research Libraries.

Jones, Kyle M. L., and Chase McCoy. 2018. "Reconsidering Data in Learning Analytics: Opportunities for Critical Research." Learning, Media and Technology 44 (1): 52-63. https://doi.org/10.1080/17439884.2018.1556216.

Jones, Kyle M. L., and Dorothea Salo. 2018. "Learning Analytics and the Academic Library: Professional Ethics Commitments at a Crossroads." College \& Research Libraries 79 (3): 304-23. https://doi.org/10.5860/crl.79.3.304.

Oakleaf, Megan. 2018. Library Integration in Institutional Learning Analytics. Louisville, CO: EDUCAUSE. https://ibrary.educause.edu/-/media/files/library/2018/11/liila.pdf. 
Rubel, Alan, and Kyle M. L. Jones. 2016. "Student Privacy in Learning Analytics: An Information Ethics Perspective." Information Society 32 (2): 143-59. https://doi.org/10.1080/01972243.2016.1130502.

Siemens, George. 2012. "Learning Analytics: Envisioning a Research Discipline and a Domain of Practice." In LAK '12: Proceedings of the 2nd International Conference on Learning Analytics and Knowledge, edited by Simon Buckingham Shum, Dragan Gašević, and Rebecca Ferguson, 48. New York: Association for Computing Machinery. https://doi.org/10.1145/2330601.2330605. 